\title{
McConnell sign: an indication for catheter-directed thrombolysis in pulmonary embolism
}

\author{
Adnan Ahmed, ${ }^{1}$ Rohan Bodapati, ${ }^{1}$ Sabah Patel ${ }^{2}$
}

'Department of Internal Medicine, Presence Saint Joseph Hospital Chicago, Chicago, Illinois, USA

${ }^{2}$ Endocrinology, Rosalind Franklin University of Medicine and Science, North Chicago, Illinois, USA

\section{Correspondence to}

Dr Sabah Patel:

sabahpatel@hotmail.com

Accepted 19 February 2020

\section{DESCRIPTION}

A 68-year-old man with no significant medical history was brought to the emergency department for an episode of syncope after exertion. $\mathrm{He}$ regained consciousness before arrival in the hospital. He reported some shortness of breath in the emergency room but denied any chest pain. In the emergency room, his heart rate was 98 beats/min, blood pressure $136 / 82 \mathrm{~mm} \mathrm{Hg}$ and $\mathrm{O}_{2}$ saturation $93 \%$ on room air. His high-sensitivity troponin was $123(<14 \mathrm{ng} / \mathrm{L})$, brain natriuretic peptide was $870 \mathrm{pg} / \mathrm{mL}(<100 \mathrm{pg} / \mathrm{mL})$ D-dimer was $2280(<500 \mathrm{ng} / \mathrm{mL})$ and ECG showed normal sinus rhythm with right bundle branch block and non-specific ST-segment and T-wave changes. CT angiogram of the chest demonstrated extensive bilateral pulmonary emboli with evidence of right ventricular (RV) dilatation and slight bowing of the interventricular septum towards the left. A point of care echocardiogram showed moderate right-sided

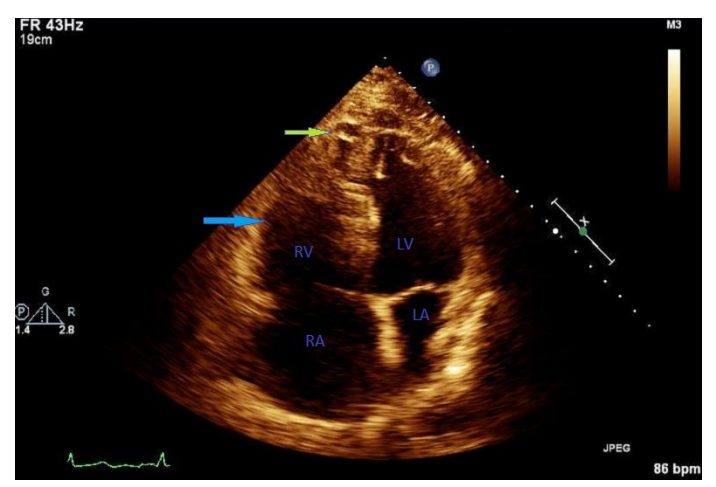

Figure 1 Image of echocardiogram during systole showing contraction of the apex of the RV (green arrow). $L A$, left atrium; $L V$, left ventricle; $R A$, right atrium; RV, right ventricle.

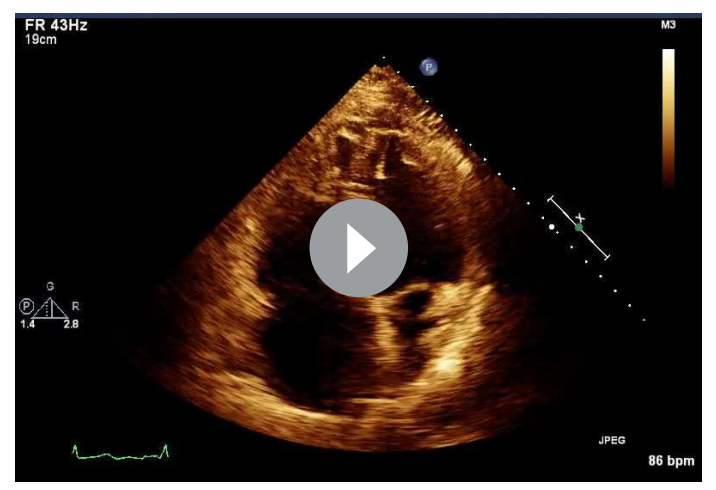

Video 1 Echocardiogram showing reduced right ventricle contractility with apical sparing.

\section{Learning points}

- Transthoracic echocardiogram remains a valuable imaging modality to assess right ventricular strain in patients with acute pulmonary embolism.

- Availability and use of bedside/point of care echocardiography can aid in the rapid diagnosis of impending haemodynamic compromise and maybe a life-saving measure.

- McConnell sign is highly specific in cases of acute massive pulmonary embolism and when present can aid in decision making to start thrombolytic therapy in the right clinical settings.

cardiac chamber enlargement and reduced right ventricular contractility with apical sparing (McConnell's sign). RV systolic pressure was noted to be $43 \mathrm{~mm} \mathrm{Hg}$ (15-25 mm Hg) (figure 1 and video 1).

He was admitted to the intensive care unit and initially started on heparin infusion followed by catheter-directed thrombolysis with tissue plasminogen activator (TPA). After obtaining consent, he was taken to the catheter laboratory, a 6-French pigtail catheter was placed into the main pulmonary artery for pulmonary artery angiogram. Two $90 \mathrm{~cm}$ Unifuse perfusion catheters were selectively placed into the right and left pulmonary arteries. Each infusion catheter was placed to continuous TPA infusion for selective thrombolysis. TPA was initiated at $0.5 \mathrm{mg} /$ hour in each catheter to a total of $1 \mathrm{mg}$ /hour for a duration of 24 hours. Follow-up angiogram demonstrated that the right pulmonary artery was entirely clear with $1 \mathrm{~cm}$ residual defect in the left upper branch. The patient was eventually transitioned to novel oral anticoagulant and discharged home. A follow-up echocardiogram done 20 days after catheter-directed thrombolysis showed normal RV size and contractility.

Pulmonary embolism affects 225000 Americans and 300000 Europeans each year. It is the third leading cause of cardiovascular mortality in North America. ${ }^{1}$ Acute RV failure constitutes high mortality in pulmonary embolism and early identification and treatment can potentially reverse RV failure. ${ }^{2}$

Echocardiography remains useful in identifying RV strain and helps justify the use of thrombolytic therapy in patients with massive acute pulmonary embolism. ${ }^{3}$ McConnell et al were the first to describe the localised pattern of dyskinesia that affects the middle free wall of the RV. ${ }^{5}$ Though it lacks sensitivity, it remains a highly specific and useful sign of acute pulmonary embolism. ${ }^{6}$ 
Contributors AA and RB: literature search, research, data acquisition and interpretation and drafting of manuscript. SP: proofreading, final drafting of the manuscript, corresponding author.

Funding The authors have not declared a specific grant for this research from any funding agency in the public, commercial or not-for-profit sectors.

Competing interests None declared.

Patient consent for publication Obtained.

Provenance and peer review Not commissioned; externally peer reviewed.

\section{REFERENCES}

1 Kahn SR, Houweling AH, Granton J, et al. Long-Term outcomes after pulmonary embolism: current knowledge and future research. Blood Coagul Fibrinolysis 2014;25:407-15.
2 Bělohlávek J, Dytrych V, Linhart A. Pulmonary embolism, part I: epidemiology, risk factors and risk stratification, pathophysiology, clinical presentation, diagnosis and nonthrombotic pulmonary embolism. Exp Clin Cardiol 2013;18:129-38.

3 Chen J-Y, Chao T-H, Guo Y-L, et al. A simplified clinical model to predict pulmonary embolism in patients with acute dyspnea. Int Heart J 2006;47:259-71.

4 Firdous N, Nasa P, Bansal A, et al. Comparison of non-invasive diagnostic tests to multi-detector CT pulmonary angiography for the diagnosis of pulmonary embolism. J Cardiovasc Dis Res 2013;4:40-3.

5 McConnell MV, Solomon SD, Rayan ME, et al. Regional right ventricular dysfunction detected by echocardiography in acute pulmonary embolism. Am J Cardiol 1996;78:469-73.

6 López-Candales A, Edelman K, Candales MD. Right ventricular apical contractility in acute pulmonary embolism: the McConnell sign revisited. Echocardiography 2010;27:614-20.

Copyright 2020 BMJ Publishing Group. All rights reserved. For permission to reuse any of this content visit

https://www.bmj.com/company/products-services/rights-and-licensing/permissions/

BMJ Case Report Fellows may re-use this article for personal use and teaching without any further permission.

Become a Fellow of BMJ Case Reports today and you can:

- Submit as many cases as you like

- Enjoy fast sympathetic peer review and rapid publication of accepted articles

- Access all the published articles

Re-use any of the published material for personal use and teaching without further permission

\section{Customer Service}

If you have any further queries about your subscription, please contact our customer services team on +44 (0) 2071111105 or via email at support@bmj.com.

Visit casereports.bmj.com for more articles like this and to become a Fellow 